\title{
Interpolacje w epiklezach bizantyjskich anafor św. Jana Chryzostoma i św. Bazylego Wielkiego
}

\author{
ks. Marek Lawreszuk \\ Uniwersytet w Białymstoku \\ Katedra Teologii Prawosławnej \\ xmlawreszuk@gmail.com
}

\begin{abstract}
ks. dr Marek Ławreszuk, Interpolation in the Epiclesis of Byzantine Anaphoras of Saint John Chrysostom and Saint Basil the Great, Elpis, 16 2014: 33-41.

Abstract: The aim of this paper is to show the interpolation in the Epiclesis of Anaphora prayers in the Liturgies of St. John Chrysostom and St. Basil the Great. The analysis will cover the changes made in the second millennium, in particular the emergence of the troparion of the third hour service, and interpolation of the words "changing it by your Holy Spirit". The text shows the genesis of adding additional words and explains what their effect was on the structure of the Anaphora prayers. As a result, proposals to solve the problems arising from historical changes in the structure of the Epiclesis and in the whole prayer of the Anaphora will be presented.

Streszczenie: Celem opracowania jest ukazanie interpolacji w epiklezach modlitw anafory Liturgii św. Jana Chryzostoma i św. Bazylego Wielkiego. Analizie zostaną poddane zmiany wprowadzone w drugim tysiącleciu, w szczególności pojawienie się troparionów nabożeństwa trzeciej godziny oraz interpolacja słów: „Przemieniając Duchem Twoim Świętym”. Tekst wskaże genezę pojawienia się dodatkowych słów oraz ukaże ich wpływ na strukturę modlitwy anafory. W efekcie przedstawione zostaną propozycje rozwiązania problemów wynikających $\mathrm{z}$ historycznych zmian w strukturze epiklezy i w całej modlitwie anafory.
\end{abstract}

Keywords: liturgy, byzantine, anaphora, epiclesis, troparia of the third hour, antitype, invocation of Holy Spirit

Słowa kluczowe: liturgia, bizantyjska, anafora, epikleza, tropariony trzeciej godziny, antytyp, przyzywanie Ducha Świętego

\section{Wprowadzenie ${ }^{1}$}

Prawosławna tradycja liturgiczna charakteryzuje się nadzwyczajną troską o zachowanie pierwotnych wzorców modlitewnych. Jest to szczególnie wyraźnie widoczne w strukturze najważniejszego nabożeństwa, tj. Liturgii, w której do dzisiejszego dnia brzmi echo czasów apostolskich. Pomimo upływu czasu, oczywistych uzupełnień i rozwoju, fundament tego nabożeństwa przejawiający się w modlitwie anafory, jest nienaruszony.

Analizując LitCHR i LitBAZ możemy stwierdzić, że historyczne zmiany w największym stopniu dotknęły fragmentów pre- i post- anaforalnych, tj. poprzedzających anaforę oraz następujących po niej. Pojawiały jednak również i w samej anaforze. W niniejszym opracowaniu przedstawimy te modyfikacje, które dotyczą najważniejszego elementu modlitwy anaforalnej, tzn. modlitwy epiklezy. Stanowi ona kulminację anafory, którą w najkrótszy sposób możemy zdefiniować jako prośbę o zesłanie Ducha Świętego. Epikleza modlitwy anafory wyodrębnia się już w III w. i od tego czasu niezmiennie jest stałym elementem modlitwy eucharystycznej Kościoła prawosławnego. W IV wieku wszystkie schematy z ich charakterystycznymi elementami, zostały przeredagowane przez Ojców Kościoła: św. Cyryla Jerozolimskiego, św. Bazylego Wielkiego i św. Jana Chryzostoma. Oczywiście ich trud nie objął wszystkich możliwych

\footnotetext{
Stosowane skróty:

AnBAZ - anafora św. Bazylego Wielkiego

AnCHR - anafora św. Jana Chryzostoma

LitBAZ - Liturgia św. Bazylego Wielkiego

LitCHR - Liturgia św. Jana Chryzostoma
}

redakcji lokalnych anafor ${ }^{2}$, jednak zamknął w ujednoliconej strukturze wszystkie najważniejsze tradycje.

Od IV w. możemy wskazać na obecność modlitwy epiklezy we wszystkich lokalnych tradycjach liturgicznych Wschodu, przy czym autonomiczny rozwój modlitwy eucharystycznej w różnych chrześcijańskich ośrodkach sprawił, że jej umiejscowienie w strukturze anafory nie jest ujednolicone.

W tradycji syryjskiej w anaforach epikleza następowała po anamnezie i poprzedzała modlitwę wstawienniczą, natomiast w egipskiej następowała po anamnezie i kończyła modlitwę anafory, $\mathrm{w}$ tradycji perskiej następowała po modlitwie wstawienniczej i kończyła anaforę, natomiast $\mathrm{w}$ tradycji bizantyjskiej, podobnie jak w syryjskiej, była uszeregowana następująco: anamneza, epikleza, modlitwa wstawiennicza ${ }^{3}$. Jak widzimy, w każdej z lokalnych tradycji obecne były wszystkie klasyczne elementy anafory. Epikleza, za wyjątkiem tradycji perskiej, występuje po części anamnetycznej, według następującej kolejności: „wspominając przeto zbawienne dzieła... - prosimy".

W powszechnej tradycji liturgicznej Kościoła chrześcijańskiego, możemy wskazać jeszcze dwa modele epiklezy: tzw. epiklezę wschodzącą oraz epiklezę Logosu.

\footnotetext{
Usystematyzowanie wszystkich istniejących anafor nie było możliwe ze względu na ich ilość. Współcześnie wiemy o 16 rytach liturgicznych Kościoła w Etiopii, jak również o 65 anaforach jakobickich i maronickich. Алымов В., Лекции по Исторической Литургике, Holy Trinity Orthodox School b.d., maszynopis, s. 58.

3 Карабинов И.А., Лекиии по титургике. Читанныя студентам (ХІХ) и (ХХ) курсов С. Петербургской Духовной Академии в 1911-1912 yч. году, Литография Богданова, Санкт-Петербург 1912, s. 45-46.
} 
W odróżnieniu od tradycyjnej epiklezy, epikleza wschodząca wkomponowana jest w całość modlitwy anafory. Modlitwa tego typu, skierowana do Boga Ojca, a następnie „przechodząca” (wschodząca) do całej Trójcy Świętej, została w liturgice określona jako epikleza wschodząca (ros. восходящций епиклесис) ${ }^{4}$. Prośba o przyjęcie darów nierozerwalnie jest związana $\mathrm{z}$ ich przemianą (cs. преложение), które możemy wyjaśnić następująco: Ojciec przyjmuje ofiarę Syna poprzez działanie Ducha. W ten sposób mogła zrodzić się wschodząca epikleza. Tego rodzaju epikleza po raz pierwszy pojawiła się w anaforze „Tradycji Apostolskiej”s oraz w niektórych anaforach syryjskich ${ }^{6}$ a także w tradycji rzymskiej i mediolańskiej

Epikleza Logosu stanowi wyjątkową modlitwę eucharystyczną, gdzie skierowana do Boga Ojca prośba związana jest $\mathrm{z}$ zesłaniem na dary Logosu. Jedyny przykład takiej epiklezy zachował się w odkrytym w 1899 roku przez A. Dmitriewskiego „Euchologionie Serapiona”.

Oprócz wskazanych wyjątków w postaci wschodzącej epiklezy oraz epiklezy Logosu, we wszystkich anaforach epikleza ma ten sam schemat. Skierowana jest do Boga Ojca i Jego prosi o zesłanie Ducha Świętego „na nas i na przedłożone Dary" oraz o przemianę chleba w Ciało Chrystusa, a wina w Krew Chrystusa.

\section{Interpolacje w modlitwie epiklezy we współczesnej tradycji liturgicznej Kościoła Prawosławnego}

Nabożeństwo eucharystyczne zostało w pełni opisane w pierwszym tysiącleciu, a jego poszczególne elementy uzyskały zarówno swój obrzędowy charakter jak również symboliczną treść. Ostateczne usystematyzowanie nie oznaczało jednak braku drobniejszych zmian. Do najbardziej subtelnych należy zaliczyć zmiany w niektórych rękopisach:

1. W „Euchologionie synajskim” IX w. (Petersburg nr 226) odnalezionym przez biskupa Porfiriusza, w epiklezie AnCHR słowa: „Jeszcze przynosimy Tobie tę duchową (cs. словесную) służbę" zastępują słowa: „duchową służbę i bezkrwawą ofiarę". Pojawiają się one również w słowiańskim rękopisie XII wieku (Sofia nr $518)^{9}$.

2. Niektóre rękopisy wskazywały różne słowa we frazie modlitwy epikletycznej „pobłogosławił je, uświęcił

\footnotetext{
4 Termin wprowadzony przez arcybiskupa Aleksego (van der Mensbrugghe). Zob. Алымов В., Лекиии..., op. cit., s. 46.

5 Ibid.

6 Арранц М., Евхаристия Востока и Запада, Москва 1999, s. 31.

Алымов В., Лекизии..., ор. cit., s. 47.

8 Алымов В., Лекиии..., ор. cit., s. 85; Paprocki H., Misterium Eucharystii. Interpretacja genetyczna liturgii bizantyjskiej, Wydawnictwo WAM, Kraków 2010, s. 89-90.

9 Орлов М. И., Литургия святаго Василия Великого, Синодальная типография, Санкт-Петербург 1909, s. 394.
}

i okazał"10. Współczesna cerkiewnosłowiańska redakcja wskazuje na formę: „благословити я, и освятиmu, и показати", zaś w rękopisach widzimy czytamy ${ }^{11}$ : „и благословити я, освятити и явити”, „благостовити я и явити”, „благословити я и проставити и освятити я и явитися" ${ }^{12}$, „и благословити и явити и святити"13, „и благословити й и освятити и показати"14.

Wśród zauważalnych zmian $\mathrm{w}$ modlitwie anafory warto wymienić pojawienie się dialogu kapłana i diakona, przesunięcie (w LitCHR) lub dodanie (w LitBAZ) słów: „Przemieniając Duchem Twoim Świętym” (gr. $\mu \varepsilon \tau \alpha \beta \alpha \lambda \dot{\omega} v$

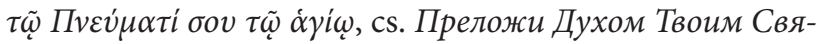
$m b l M)$ oraz wprowadzenie troparionu nabożeństwa trzeciej godziny do modlitwy anafory.

W historii Kościoła prawosławnego całe nabożeństwo eucharystyczne zmieniało się, rozwijało i poszerzało. Zmiany te, w obrębie elementów nieanaforalnych były bardziej zauważalne ${ }^{15}$. Jednak to zmiany w anaforze, w jądrze całej Liturgii, wzbudzają największą ciekawość a nawet obawy.

\section{2. „Przemieniając Duchem Twoim Świętym"}

Słowa „Przemieniając Duchem Twoim Świętym” pojawily się najpierw w LitCHR, jednak ich pierwotne miejsce różni się od współczesnego. W kodeksie Barberini gr. 336 (VIII w.) powtarzano je dwukrotnie, przy błogosławieństwie Chleba brzmiały: „I uczyń przeto chleb ten najczcigodniejszym Ciałem Chrystusa Twego, przemieniając Duchem Twoim Świętym” oraz kielicha: „A co w kielichu tym najczcigodniejszą Krwią Chrystusa Twego, przemieniając Duchem Twoim Świętym" ${ }^{\prime \prime}$. Stały się one wkrótce odrębną kwestią wygłaszaną w czasie wspólnego błogosławieństwa Ciała i Krwi. W ten sposób zostały zapisane w LitCHR w „Euchologionie” J. Goara (1730): prezbiter „I uczyń przeto chleb ten..., diakon „amen”, prezbiter „A co w kielichu...," diakon „amen”, prezbiter „Przemieniając Duchem Twoim Świętym”, diakon „amen, amen, amen”"17. Podwójnie wygłoszenie tych słów pojawia się również w „Euchologionie" Synajskim IX w. (Petersburg nr 226).

Według archimandryty Kipriana, w LitCHR słowa te, pojawiające się raz lub dwa razy, „są w pełni zgodne z ogólnym kontekstem modlitwy"18.

\footnotetext{
10 Boska Liturgia świętego ojca naszego Bazylego Wielkiego, Warszawska Metropolia Prawosławna, Warszawa 2005, s. 91.

11 Орлов М. И., ор. cit., стр. 203.

12 „Służebnik” XV w. Sofijska Biblioteka nr 530.

13 „Służebnik” XVI w. Sofijska Biblioteka nr 617.

14 „Służebnik” XV w. Sofijska Biblioteka nr 531.

15 Zob. m.in. rozwój Liturgii eucharystycznej w opracowaniu o. Miguela Arranza. Арранц М., Евхаристия Востока и Запада..., ор. cit., s. 40-49.

16 Zob. Parenti S. i Velkovska E., red., L'Eucologio Barberini gr. 336, C. L.V.-Edizioni Liturgiche, Roma 1995, s. 35.

17 Goar J., Euchologion Sive Rituale Graecorum, Graz 1960, II, s. 62;

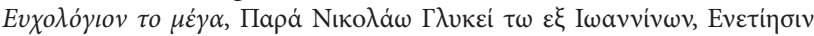
1767 , s. 52.

18 Керн К., Евхаристия..., ор. cit., s. 192.
} 
Zauważamy je również w LitBAZ, gdzie naruszają dotychczasową strukturę błogosławieństwa [1] Ciała oraz [2] Krwi [3] „wylanej za życie świata”. Starszy schemat epiklezy wskazywał na 3 kwestie prezbitera, po których diakon wygłaszał „amen”. W wyniku inspiracji LitCHR słowa „przemieniając..." uzupełniają ostatnią kwestię prezbitera [3], która przyjmuje następującą formę: prezbiter „Chleb ten...” diakon „amen”, prezbiter „A co w tym kielichu...”, diakon „amen”, prezbiter „Wylaną za życie świata”, diakon „amen”, prezbiter „Przemieniając...”, diakon „amen, amen, amen”" Współcześnie ich transpozycja jest dosyć jednoznacznie określana jako „zbyteczna”, a nawet „przeciwstawna” z treścią modlitwy LitBAZ, w której dla bezpośredniego działania Ducha Świętego wskazuje się działanie Ojca poprzez Ducha $^{20}$. O tym, że współczesna redakcja tego tekstu nie stanowi oryginalnej wersji świadczą m.in. greckie i słowiańskie rękopisy, w których słów tych w LitBAZ brak ${ }^{21}$. W jednym z najstarszych „Służebników” słowiańskich (XIII w.) czytamy: „... i okazał [i przeżegnawszy mówi] Chleb ten najdroższe Ciało Pana i Boga i Zbawiciela naszego Jezusa Chrystusa [i następnie przeżegnawszy kielich] Kielich ten najdroższą Krew Pana i Boga i Zbawiciela naszego Jezusa Chrystusa [a to mówi żegnając oba naczynia] Wylaną za życie świata. Nas wszystkich spożywających..."22.

Dodatek ten pojawia się jedynie w 11 z 48 greckich rękopisów analizowanych przez prof. Michaiła Orłowa ${ }^{23}$. W weneckim wydaniu „Służebnika” na marginesie AnBAZ pojawia się komentarz z odwołaniem do „Pidalionu” Nikodema, który wskazuje, że słowa te odnoszą się wyłącznie do LitCHR, LitBAZ nie dotyczą $a^{24}$.

Wielu liturgistów i teologów, m.in. Wasilij Bołotow, wskazywało na niebywałą niegramatyczność zestawienia słów „przemieniając...” z tekstem AnBAZ. Krytyczny rozbiór gramatyczny greckiego tekstu został przedstawiony w pracy prof. Bołotowa oraz książce archimandryty Kipriana Kerna ${ }^{25}$.

Wtrącenie to dzieli modlitwę epikletyczną oddzielając uświęcające ją słowa. Jak wskazuje archimandryta Kiprian Kern słowami uświęcającymi modlitwę epikletyczną, czyli stawiającymi odpowiedni akcent znaczeniowy, w przypadku AnCHR są słowa: „I uczyń przeto”, natomiast w przypadku AnBAZ: „pobłogosławił je, uświęcił i okazał”26.

Archimandryta Kiprian jednoznacznie głosi, że zostały one „błędnie i absolutnie nieodpowiednio wprowadzone w słowiańskie służebniki i w tekst LitBAZ”27. Od roku 1853 wtrącenie to nie pojawia się w drukowanych greckich „Liturgikonach"28.

Taką formę odnajdziemy m.in. w „Wielkim Euchologionie”. Ibid., s. 71.

Zob. Арранц М., Евхаристия Востока и Запада..., op. cit., s. 27.

Керн К., Евхаристия, Москва 1999, s. 192.

Соловеикий Служебник, РНБ. Солов. № 1017, ХІІІ в., b.d., s. 8.

Орлов М. И., ор. сit., стр. 208.

Керн К., Евхаристия..., ор. cit., s. 192.

Болотов В. В., Заметки по поводу текста титургии святого Василия Великого, „Християнское чтение, 3 1914, s. 286. Керн К., Евхаристия..., ор. cit., s. 192.

26 Керн К., Евхаристия..., ор. cit., s. 193.

27 Ibid., s. 185.

28 Ibid., s. 193.
Mając świadomość spójności AnCHR i AnBAZ musimy w nich dostrzegać również ich odmienny styl i indywidualną formę, w której zostały zapisane. W tym przypadku nie możemy dopuszczać do przewartościowania tekstu AnBAZ w duchu tekstu św. Jana. Rozwiązanie wydaje się oczywiste - interpolacja powinna być zachowana w tekście AnCHR natomiast $\mathrm{w}$ AnBAZ błogosławieństwo chleba i wina należałoby kończyć słowami: „Wylaną za życie świata. Amen, amen, amen".

\section{Tropariony nabożeństwa trzeciej godziny}

W XV w. w modlitwie kanonu eucharystycznego LitCHR pojawił się troparion nabożeństwa trzeciej godziny: „Panie, który Najświętszego Twego Ducha o trzeciej godzinie na Twych apostołów zesłałeś..." ${ }^{29}$. Tekst ten wyrażał pobożną potrzebę wstawiennictwa, odczuwaną przez sprawujących sakrament kapłanów i dzięki czemu został, dosyć nieodpowiednio, umieszczony w modlitwie epiklezy. Słowa te zostały zapisane w LitCHR redakcji Jakuba Goara ${ }^{30}$. W wyniku inspiracji tekstem LitCHR pojawily się one również w greckich redakcjach LitBAZ, m.in. w „Wielkim Euchologionie" z $1767 \mathrm{r}^{31}$. Słowa troparionu rozdzielają modlitwę epiklezy, stanowiąc interpolację, która wykazuje przy tym dwie negatywne cechy: sprzeczność logiczną oraz niespójność językową.

\section{A. Geneza wprowadzenia nowego tekstu}

Powodem, który sprzyjał pojawieniu się dodatkowego tekstu w modlitwie anaforalnej, stała się polemika z Kościołem rzymskokatolickim, a w szczególności z pojawieniem się scholastycznej koncepcji formuły sakramentalnej. Spór o moment przemiany darów stanowił przykład wykorzystania rzymskokatolickich założeń dla potwierdzenia ortodoksyjnej teologii. Kościół prawosławny nie zna pojęcia „formuła sakramentalna”. Sakrament stanowi tajemnicę, misterium, w czasie którego zstępuje Łaska Boża. Daremna i bezcelowa jest dyskusja, w którym dokładnie momencie i w związku z jakimi słowami, cud ten następuje. Walka z rzymskokatolicką koncepcją formuly sakramentalnej doprowadziła w XIV w. do próby podkreślenia centralnego miejsca epiklezy w modlitwie anafory. W wyniku tej tendencji moment epiklezy został wyodrębniony z tekstu anafory poprzez wprowadzenie „przygotowującej modlitwy" tj. troparionów trzeciej godziny. Zmiana ta została przeprowadzona początkowo w tekście AnCHR, chociaż już w XV wieku pojawiła się w AnBAZ. Jak wskazuje archi-

\footnotetext{
29 Алымов В., Лекции..., ор. cit., s. 63.

30 Zob. Goar J., Euchologion..., op. cit., s. 62.

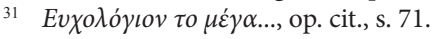


mandryta Filaret Zacharowicz, w słowiańskich rękopisach XII-XV wieku, wydawanych zarówno w synodalnej typografii jak i w Wenecji, w tekście LitCHR tropariony trzeciej godziny nie pojawiały $s_{i e ̨}^{32}$. Pierwsze słowiańskie redakcje „Służebników” wprowadziły zmiany w tekście LitBAZ dopiero w XVII wieku. W wielu słowiańskich kodeksach XV-XVI w. nie pojawiła się nowa interpolacja (Watopedi nr 133/744 z XV w., Pantelejmon nr 435 z XVI w., Synaj $\mathrm{nr}$ 986, Watykan nr $1213 \mathrm{z}$ połowy XVI w.). Tekst troparionu nie pojawiał się nawet $\mathrm{w}$ drukowanych „Służebnikach” („Służebnik” wenecjański z 1554 r. z drukarni Bożydara Wukowicza). Według archimandryty Kipriana Kerna „w praktyce Kościoła na Rusi XII-XIV w. troparion ten nie był czytany"33.

Biskup Porfiriusz Uspienskij jako źródło pojawienia się interpolacji wskazuje działalność patriarchy Filoteusza, liturgicznego reformatora, autora „Diataksis”34. Kijowski prof. Aleksiej Dmitriewskij, wybitny liturgista, odrzucił twierdzenie biskupa Porfiriusza, wskazując jednocześnie, iż początków interpolacji należy upatrywać w Wenecji, gdzie w XVI w. drukowano księgi liturgiczne $e^{35}$.

W jednym z rękopisów XI w. (Grottaferrata) pojawia się co prawda tekst troparionów 3 godziny, wskazany do czytania przez kapłana, jednak umieszczony jest on nie w tekście modlitwy anafory, lecz po Eucharystii kapłana ${ }^{36}$.

\section{B. Powielenie i powtórzenie próśb}

Jedną z przyczyn pojawienia się troparionu 3 godziny odnajdujemy w treści modlitw liturgicznych. Słowa epiklezy zawierają prośbę do Boga o zesłanie Ducha Świętego „na nas i na przedłożone dary”. Określenie "na nas” wskazuje na duchownych, którzy sprawują Boską Liturgię i pojawia się już w najstarszym rękopisie Liturgii apostoła Jakuba ${ }^{37}$. Słowa te oznaczają obawę przed niegodnym sprawowaniem Świętych Tajemnic i troskę, aby osobista grzeszność nie wpłynęła na składaną Bogu ofiarę. Jeśli przeanalizujemy modlitwy Liturgii, echo tych odczuć odnajdziemy w:

1. Modlitwie proskomidii po postawieniu darów na ołtarzu: „Panie Boże wszechmogący, jedyny święty, który przyjmujesz ofiarę chwały od tych, którzy wzywają Ciebie całym sercem, przyjmij też modlitwę nas grzesznych i zanieś na święty Twój ołtarz. Uczyń nas godnymi składania Tobie darów i ofiar duchowych, za nasze grzechy i za nieświadomości ludu. Uczyń nas godnymi, abyśmy znaleźli łaskę przed Tobą, aby nasza ofiara była Tobie przyjemną i aby Duch łaski Twojej,

\footnotetext{
Захарович Ф., Чин титургии св. Иоанна Златоустого по изложению старопечатных, новоисправленного и древлеписменных Служебников: Опьт сличения старопечатных и исправленных иерковнобогослужебных книг с древлеписьменными, Москва 1899, s. 90.

33 Керн К., Евхаристия..., ор. cit., s. 196.

34 Ibid., s. 194.

35 Ibid., s. 195.

36 Ibid., s. 194.

37 Карабинов И. А., Лекиии..., ор. cit., s. 169-170.
}

Dobry, spoczął na nas i na tych przedłożonych darach, i na całym Twoim ludzie"38.

2. Modlitwie wielkiego wejścia: „Nikt, kto poddał się cielesnym pożądliwościom i rozkoszom, nie jest godny ani przystępować, ani przybliżać się, ani służyć Tobie, Królu Chwały [...]Przeto błagam Ciebie, jedynego dobrego i skłonnego do wysłuchania: wejrzyj na mnie grzesznego i nieużytecznego sługę Twego, i oczyść moją duszę i serce od złego sumienia, a także mocą Świętego Twego Ducha uczyń mnie, przyobleczonego łaską kapłaństwa, godnym stanąć przed tym świętym Twoim ołtarzem i sprawować świętą czynność tajemnicy przeczystego Twojego Ciała i najczcigodniejszej Krwi. Do Ciebie przeto przychodzę skłoniwszy moją głowę i błagam Cię: Nie odwracaj Oblicza swego ode mnie ani nie odrzucaj mnie z grona Twych dzieci, ale uczyń mnie, grzesznego i niegodnego Twego sługę, godnym złożenia tych darów...” ${ }^{\text {. }}$.

3. Drugiej modlitwie wiernych: „Znowu i wielokroć przypadamy do Ciebie i błagamy Cię, Dobry i Przyjacielu człowieka, abyś wejrzawszy na nasze błaganie, oczyścił nasze dusze i ciała $\mathrm{z}$ wszelkiej zmazy ciała i ducha, i pozwolił nam stanąć przed świętym Twoim ołtarzem niewinnie i bez osądzenia..."40.

4. Pierwszej modlitwie wiernych: „...Przyjmij, Boże, nasze błagania, uczyń nas godnymi składania Tobie błagań i żarliwych próśb oraz bezkrwawych ofiar za cały Twój lud. Spraw, abyśmy my, których powołałeś do tej służby mocą Ducha Twego Świętego, bez osądzenia i nienagannie, z czystym świadectwem naszego sumienia, wzywali Ciebie, w każdym czasie i miejscu, abyś wysłuchując nas, był dla nas miłosiernym w obfitości Twojej dobroci..." ${ }^{\prime 1}$.

Jak widzimy, poczucie niegodności i grzeszności prowadzi do pokutnej modlitwy i prośby o przyjęcie składanej ofiary. Rozwinęło się ono w części przedanaforalnej, a w $\mathrm{XV}$ w. doprowadziło również do pojawienia się w samej anaforze prośby o przebaczenie. Poczucie niegodności i grzeszności rozwinęło również wezwania poprzedzające Liturgię oraz moment ofiarowania darów, poprzez pojawienie się krótkiej modlitwy: „Boże oczyść mnie grzesznego i zmiłuj się ". Poczucie niegodności oraz dążenie do oczyszczenia sprawiły także, że we współczesnej praktyce w Liturgii wygłaszana jest modlitwa, która nie została zapisana w „Liturgikonach”, a pochodzi ze starej aleksandryjskiej praktyki. Mowa o aleksandryjskiej modlitwie rozgrzeszenia opartej na starotestamentowej modlitwie święta Dnia Pojednania (Jom kippur) - „Daruj, przebacz i odpuść...” (cs. Ослаби, остави, прости...”) $)^{42}$. Modlitwa ta pojawia

\footnotetext{
38 Boska Liturgia świętego ojca naszego Jana Chryzostoma, Warszawska Metropolia Prawosławna, Warszawa 2001, s. 72.

39 Ibid., s. 62-64.

40 Ibid., s. 61.

41 Ibid., s. 58-59.

42 Por. również szóste błogosławieństwo Tefila. Арранц М., і Рубан Ю., История византийского типикона “Око иерковное". Часть I. Предвизантийская эпоха. Исторические свидетельства о молитве древних християн (до V в.), Журнал “Нева," Санкт-Петербург 2003, s. 68.
} 
się we wczesnochrześcijańskim nabożeństwie jako forma powszechnego pojednania i prośba o przebaczenie. Głośno wygłaszana przez duchownych i wiernych przed przyjęciem Eucharystii, stała się substytutem niepraktykowanej częstej spowiedzi. Modlitwa ta pojawia się w „Horologionach” tradycji palestyńskiej około XIII w., przy czym nie była ona związana $\mathrm{z}$ Liturgią, a nabożeństwem typika ${ }^{43}$. Obecność i umiejscowienie tej modlitwy w nabożeństwie typika, wskazuje że poprzedzała ona Modlitwę Pańską i późniejsze przyjęcie Eucharystii. Współcześnie występuję ona w nabożeństwie typika, w modlitwach wieczornych, oraz w siódmej modlitwie kapłańskiej jutrzni: „Przeto prosimy Ciebie, jeśli zgrzeszyliśmy czymś do tej godziny, słowem lub uczynkiem, lub myślami, dobrowolnie lub mimowolnie, zapomnij, wymaż, przebacz" ${ }^{44}$.

Pojawienie się troparionów 3 godziny stanowi więc powielenie już istniejącego motywu pokajania. Możemy oczywiście określić taką niespójność jako cechę drugorzędną, jednak w zestawieniu z modlitwą anafory, wchodzącą na wyżyny intelektualne, stanowiącą perłę chrześcijańskich tekstów liturgicznych, wyraźnie ukazuje się nam jej nieodpowiedniość w tym miejscu. Tekst modlitwy anafory jest uniwersalny i powszechny, staje się modlitwą wspólnoty, skierowaną w stronę Boga Ojca. Wtrącenie, które jakoby wspierało wiarę kapłana-liturga rozbija ten idealny, uniwersalny charakter modlitwy. Wtrącenie staje się ponadto duplikacją wcześniej przytoczonych modlitw w intencji sprawującego ofiarę, jeszcze bardziej zmieniając akcent eucharystyczny. Wszystkie przedanaforalne elementy mogą przyjmować charakter usprawiedliwienia i prośby o przebaczenie, stanowiąc tym samym ukazanie świadomości wspólnoty przed wielkością składanej ofiary. Sam moment anafory powinien jednak skupiać się na tej treści, którą wyraża anafora, i która jest celem Liturgii. Eucharystia oznacza dziękczynienie i koncentruje się na zbawczym dziele Jezusa Chrystusa. Uzupełnienie jej o element pokutny, dotyczący kapłana-liturga, narusza więc jej spójność i jednoznaczny uniwersalny charakter.

W modlitwie AnBAZ jest zresztą już wskazanie na odkupieńcze dzieło Boże, w świetle którego blakną wszelkie ludzkie grzechy. W zstąpieniu Zbawiciela, Jego nauce i ofierze, Bóg uczynił nas: „dla Siebie ludem wybranym, królewskim kapłaństwem, narodem świętym, i oczyścił nas w wodzie i uświęcił Duchem Świętym, [...] torując tym każdemu ciału drogę ku zmartwychwstaniu"45. W modlitwie epikletycznej AnBAZ słyszymy nawet : „Przeto i my, Władco Najświętszy, grzeszni i niegodni Twoi słudzy, którym dozwalasz służyć świętemu Twemu ołtarzowi nie dla naszych zasług, gdyż nic dobrego nie uczyniliśmy na ziemi, ale $z$ Twego miłosierdzia i Twojej litości, którą obficie na nas wylałeś, z ufnością zbliżamy się do świętego Twego ołtarza i ofiarując podobieństwa świętego Ciała i Krwi Chrystu-

\footnotetext{
43 Скабалланович М., Толковый Типикон. Объяснительное избяснение Типика с историческим введением, Издание Сретенского монастыря, Москва 2004, s. 392

44 Wieczernia, Jutrznia, Prokimenony, Alleluja, Rozesłania, Kalendarz Liturgiczny, Warszawska Metropolia Prawosławna, Warszawa 2006, s. 55

45 Boska Liturgia świętego ojca naszego Bazylego Wielkiego, op. cit., s. 85.
}

sa Twego, modlimy się do Ciebie i Ciebie przyzywamy"46. W końcowych wersetach modlitwy wstawienniczej AnBAZ czytamy także: „Pamiętaj, Panie, w ogromie swej litości i o mnie niegodnym, daruj mi wszystkie grzechy świadome i nieświadome, i z ich powodu nie odbieraj łaski Świętego Twego Ducha od leżących tutaj darów" ${ }^{47}$.

\section{Zmiana adresata modlitwy}

Dodatkowy tekst w modlitwie anafory zmienia również adresata modlitwy. Są to słowa skierowane do Boga Ojca. Również epikleza, tj. prośba o zesłanie Ducha Świętego na dary skierowane są do Boga Ojca. W troparionach adresatem staje się Syn Boży, po czym, wracając do oryginalnego tekstu anafory modlitwa ponownie skierowana jest do Boga Ojca. Na podstawie poniższej tabeli widzimy, że zmiana adresata pojawia się jedynie w interpolacji, tym samym stanowiąc jedyne źródło naruszenia spójności tekstu.

Tabela 1: Adresaci modlitw anafory Liturgii św. Jana Chryzostoma i św. Bazylego Wielkiego ${ }^{48}$

\begin{tabular}{|c|c|c|}
\hline $\begin{array}{l}\text { Liturgia } \\
\text { św. Jana } \\
\text { Chryzos- } \\
\text { toma }\end{array}$ & $\begin{array}{l}\text { Bóg } \\
\text { Ojciec }\end{array}$ & $\begin{array}{l}\text { Ty i Jednorodzony Twój Syn, i Duch Twój Święty. [...] } \\
\text { dzięki składamy Tobie i Jednorodzonemu Twemu } \\
\text { Synowi, i Duchowi Twemu Świętemu. [...] } \\
\text { Ty i Jednorodzony Twój Syn, i Duch Twój Święty. } \\
\text { Syna Twego Jednorodzonego dałeś, [...] } \\
\text { I uczyń przeto chleb ten najczcigodniejszym } \\
\text { Ciałem Chrystusa Twego. [...] } \\
\text { A co w kielichu tym najczcigodniejszą Krwią } \\
\text { Chrystusa Twego. [...] } \\
\text { Przemieniając Duchem Twoim Świętym. [...] } \\
\text { imię Twoje, Ojca i Syna, i Świętego Ducha. }\end{array}$ \\
\hline $\begin{array}{l}\text { Liturgia św. } \\
\text { Bazylego } \\
\text { Wielkiego }\end{array}$ & $\begin{array}{l}\text { Bóg } \\
\text { Ojciec }\end{array}$ & 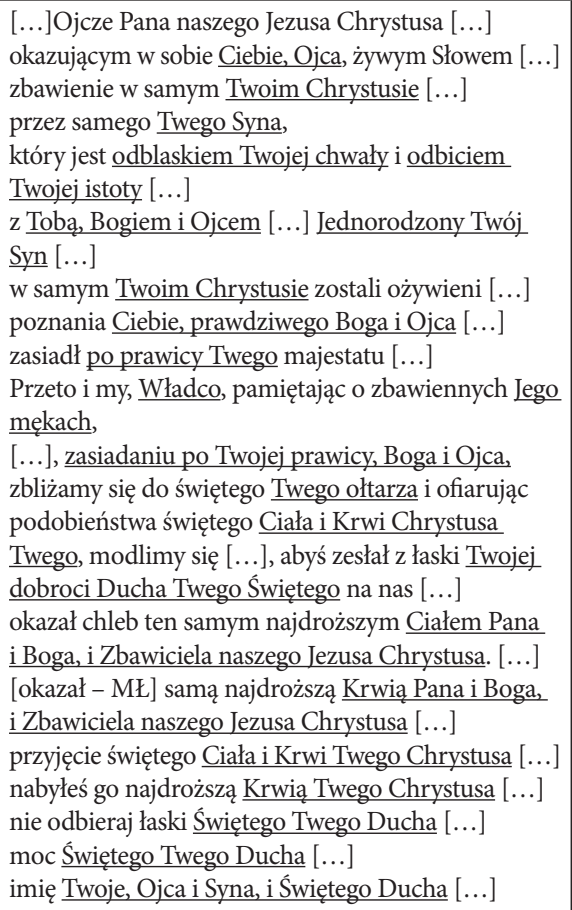 \\
\hline
\end{tabular}

\footnotetext{
46 Ibid., s. 88.

47 Ibid., s. 100.

48 Boska Liturgia świętego ojca naszego Jana Chryzostoma, op. cit., s. 77-88; Boska Liturgia świętego ojca naszego Bazylego Wielkiego, op. cit., s. $78-101$.
} 


\begin{tabular}{|l|l|l|}
\hline $\begin{array}{l}\text { Troparion } \\
\text { trzeciej } \\
\text { godziny }\end{array}$ & $\begin{array}{l}\text { Bóg } \\
\text { Syn }\end{array}$ & $\begin{array}{l}\text { Panie, który Najświętszego Twego Ducha o trze- } \\
\text { ciej godzinie na Twych Apostołów zesłałeś }[\ldots]\end{array}$ \\
\hline
\end{tabular}

\section{Wpływ na modlitwę anafory}

Troparion 3 godziny narusza również treść anafory. $\mathrm{O}$ ile naruszenie to w AnCHR ma charakter subtelny, o tyle w AnBAZ, sprawia, że wątek głównej modlitwy liturgicznej zostaje poważnie naruszony. Tropariony przerywają epiklezę AnBAZ. Miejsce, w którym się pojawiają nie tylko przerywa wątek modlitwy, ale rozrywa jedno, bardzo treściwe zdanie na dwa, które oddzielnie nie są zrozumiałe.

Tabela 2: Tekst modlitwy epikletycznej Liturgii św. Bazylego Wielkiego ${ }^{49}$

\begin{tabular}{|c|c|}
\hline \multicolumn{2}{|c|}{ Tekst modlitwy epikletycznej Liturgii św. Bazylego Wielkiego } \\
\hline Tekst pierwotny & Interpolacje i wtrącenia \\
\hline \multirow[t]{3}{*}{$\begin{array}{l}\text { K (kapłan): Przeto i my, Władco Naj- } \\
\text { świętszy, grzeszni i niegodni Twoi } \\
\text { słudzy, którym dozwalasz służyć } \\
\text { świętemu Twemu ołtarzowi nie dla } \\
\text { naszych zasług, gdyż nic dobrego nie } \\
\text { uczyniliśmy na ziemi, ale z Twego } \\
\text { miłosierdzia i Twojej litości, którą ob- } \\
\text { ficie na nas wylałeś, z ufnością zbli- } \\
\text { żamy się do świętego Twego ołtarza i } \\
\text { ofiarując podobieństwa świętego Cia- } \\
\text { ła i Krwi Chrystusa Twego, modlimy } \\
\text { się do Ciebie i Ciebie przyzywamy, } \\
\text { Święty Świętych, abyś zesłał z łaski } \\
\text { Twojej dobroci Ducha Twego Świę- } \\
\text { tego na nas i na leżące tutaj te dary, } \\
\text { pobłogosławił je, uświęcił i okazał }\end{array}$} & \\
\hline & $\begin{array}{l}\text { K: Panie, który o trzeciej godzi- } \\
\text { nie zesłałeś na Twych Apostołów } \\
\text { Najświętszego Twego Ducha, nie } \\
\text { odbieraj Go nam, dobry, lecz } \\
\text { odnów nas, modlących się do } \\
\text { Ciebie. D (diakon): Serce czyste } \\
\text { stwórz we mnie, Boże, i ducha } \\
\text { prawego odnów w mym wnętrzu. } \\
\text { K: Panie, który o trzeciej godzi- } \\
\text { nie... } \\
\text { D: Nie odrzucaj mnie od swego } \\
\text { oblicza, i Ducha Twego Świętego } \\
\text { nie odbieraj mi. } \\
\text { K: Panie, który o trzeciej godzi- } \\
\text { nie... }\end{array}$ \\
\hline & $\begin{array}{l}\text { D: Pobłogosław, władyko, święty } \\
\text { chleb. }\end{array}$ \\
\hline \multirow[t]{2}{*}{$\begin{array}{l}\text { K: Chleb ten samym najdroższym } \\
\text { Ciałem Pana i Boga, i Zbawiciela } \\
\text { naszego Jezusa Chrystusa. }\end{array}$} & \\
\hline & $\begin{array}{l}\text { D: Amen. Pobłogosław, władyko, } \\
\text { święty kielich. }\end{array}$ \\
\hline \multirow[t]{2}{*}{$\begin{array}{l}\text { K: A co w tym kielichu samą naj- } \\
\text { droższą Krwią } \\
\text { Pana i Boga, i Zbawiciela naszego } \\
\text { Jezusa Chrystusa. }\end{array}$} & \\
\hline & D: Amen. \\
\hline K: Wylaną za życie świata. & \\
\hline
\end{tabular}

49 Boska Liturgia świętego ojca naszego Bazylego Wielkiego, op. cit., s. 90-92.

\begin{tabular}{|c|c|}
\hline & D: Amen. \\
\hline & $\begin{array}{l}\text { D: Pobłogosław, władyko, chleb } \\
\text { i kielich. }\end{array}$ \\
\hline & $\begin{array}{l}\text { K: Przemieniając Duchem Two- } \\
\text { im Świętym. }\end{array}$ \\
\hline & D: Amen. Amen. Amen. \\
\hline & $\begin{array}{l}\text { D: Pamiętaj o mnie grzesznym, } \\
\text { władyko święty. }\end{array}$ \\
\hline $\begin{array}{l}\text { K: Nas wszystkich, spożywających z } \\
\text { jednego chleba i z jednego kielicha, } \\
\text { zjednocz razem we wspólnocie jed- } \\
\text { nego Ducha Świętego, aby dla nikogo } \\
\text { z nas przyjęcie świętego Ciała i Krwi } \\
\text { Twego Chrystusa nie było na sąd } \\
\text { lub potępienie, ale abyśmy znaleźli } \\
\text { miłosierdzie i łaskę ze wszystkimi } \\
\text { świętymi, których od wieków sobie } \\
\text { upodobałeś, z Praojcami, Ojcami, Pa- } \\
\text { triarchami, Prorokami, Apostołami, } \\
\text { Ewangelistami, Kaznodziejami, Mę- } \\
\text { czennikami, Wyznawcami, Nauczy- } \\
\text { cielami, i z wszystkimi duszami spra- } \\
\text { wiedliwych, które w wierze spoczęly. }\end{array}$ & \\
\hline
\end{tabular}

Skierowane do Boga Ojca słowa „....modlimy się do Ciebie i Ciebie przyzywamy, Święty Świętych, abyś zesłał $\mathrm{z}$ łaski Twojej dobroci Ducha Twego Świętego na nas i na leżące tutaj te dary, pobłogosławił je, uświęcił i okazał”, przez wtrącenie troparionów tracą swój cel. W tym miejscu naturalnie pojawia się pytanie: „Cóż Bóg ma ukazać?”"50. W słowiańskich „Służebnikach” słowa te kończą się kropką, podczas gdy tekst pozbawiony troparionów ukazuje nam prawdziwy, czytelny wymiar tych słów. W modlitwie prosimy o zesłanie Ducha Świętego na nas i na dary, błogosławieństwo darów, uświęcenie ich i okazanie ... chleba będącego Ciałem Chrystusa oraz „tego co w kielichu” będącego Krwią Chrystusa. Jak widzimy, tropariony przerwały więc jedno z najważniejszych zdań AnBAZ, zmieniając jednocześnie jej ukierunkowanie i naruszając treść. Najbardziej żarliwa modlitwa rozpływa się w troparionie trzeciej godziny i wersetach Psalmu 50.

\section{E. Wnioski}

Na szkodliwość tego liturgicznego wtrącenia wskazywano wielokrotnie. W końcu XVIII wieku, w Grecji, nieznany z imienia „,ierokiriks” (kapłan-kaznodzieja), pozostawił teologiczny traktat, który w skrócie przytoczył biskup Porfiriusz. We fragmencie dotyczącym wprowadzonego troparionu autor określił go jako wtrącenie „,nieprawidłowe i nierozumne”, a nawet „anty Chrystusowa bezczelność” ${ }^{51}$.

$\mathrm{W}$ tradycji greckiej troparion został usunięty $\mathrm{z}$ „Liturgikonów”. Podobną praktykę zastosowały również starożytne patriarchaty tradycji greckiej. Tropariony nie są tam czytane $^{52}$. We współczesnych „Służebnikach” cerkiewnosłowiańskich, wydawanych przez Patriarchat Moskiewski,

50 Zob. Деснов Николай, Еще несколько слов об известных расхождениях между русскими и греками в литургиях святителей Василия Великого и Иоанна Златоуста, w: Богословские труды, 31 1992, s. 87.

51 Керн К., Евхаристия..., ор. cit., s. 196.

52 Деснов Николай, op. cit., s. 87. 
tropariony zostały wyodrębnione $\mathrm{w}$ nawiasach kwadratowych ${ }^{53}$.

Tropariony 3 godziny nie wpływają oczywiście na znaczenie Liturgii, lecz naruszają harmonię i spójność klasycznej anafory. Nieujednolicona praktyka wpływa również negatywnie na poczucie jedności powszechnego Prawosławia w sytuacji, kiedy nabożeństwo sprawowane jest jednocześnie przez duchowieństwo tradycji greckiej i słowiańskiej.

W liście do archimandryty Antoniego Kapustina, metropolita moskiewski Filaret, podał w wątpliwość grecką korektę tekstu modlitwy epikletycznej, z której usunięto tropariony 3. godziny. Na stwierdzenie metropolity: „[...] jeśli i my powinniśmy uczynić to samo, zrodzi się dla nas trudność, albowiem mamy podstawy zachować stary obyczaj, który przyjęliśmy od Kościoła w Grecji" archimandryta Antoni odpowiedział: „Oszczerstwo! On [tj. patriarcha konstantynopolitański] niczego nie wykreślał, albowiem tego nikt wcześniej nie wprowadzał" ${ }^{54}$.

\section{Zakończenie}

Analizowane przez nas dwie interpolacje AnBAZ i AnCHR w połowie XIX wieku zostały usunięte z greckich ksiąg liturgicznych. Ze względu na jedność modlitwy anafory należałoby dążyć do skreślenia tych interpolacji z praktyki słowiańskiej, co jest już zresztą obserwowane we współczesnych wydaniach „Służebników” Patriarchatu Moskiewskiego.

Tropariony trzeciej godziny nie znajdują miejsca w AnCHR i AnBAZ. Wśród proponowanych przez liturgistów rozwiązań należy wskazać dwa: ich usunięcie z modlitwy anafory, co będzie zgodne z tradycją grecką oraz przesunięcie przed modlitwę epiklezy (po słowach „To, co Twoje, od Twoich...") - sugerowane w thumaczeniach ks. H. Paprockiego ${ }^{55}$.

Fraza „Przemieniając...” powinna być usunięta $\mathrm{z}$ tekstu AnBAZ, co będzie zgodne z tradycją grecką oraz jak wcześniej wskazaliśmy, nie naruszy jedności tematycznej anafory. W AnCHR transpozycja przyjęta już w IX w., nie burzy logiki tekstu i nie prowadzi do zmian.

Przyczyn ewentualnej redakcji tekstów nie należy doszukiwać się wyłącznie w historycznym rozwoju modlitwy, albowiem, w takim przypadku należałoby dążyć do przywrócenia apostolskiego zwyczaju łamania chleba, tj. przywrócenia praktyki pierwszych wieków ${ }^{56}$. Faktorem

\footnotetext{
53 Ibid., s. 86-96.

54 Керн К., Евхаристия..., ор. cit., s. 198.

55 Kolejność przedstawiona w tłumaczeniu opublikowanym na stronie www.liturgia.cerkiew.pl nie została zachowana w „Służebniku” wydanym przez Warszawską Metropolię Prawosławną. Zob. Boska Liturgia świętego ojca naszego Bazylego Wielkiego, op. cit., s. 89-90; autorski przekład ks. H. Paprockiego: http://www.liturgia.cerkiew.pl/pages/File/docs/gia bazylego_wielkiego.pdf, dostęp 22.05.2014.

56 Mówi o tym archim. Kiprian Kern: „Молитву эпиклезы можно рассматривать с точки зрения, например, исключительно литургикоархеологической. Ее можно понимать и изучать, как просто (и только) литургический феномен, явление истории, занимающее мысль только историка церковного обряда. Это подход односторонний, узкий, и потому неправильный. Удовлетворительного ответа он дать нам не сможет". Керн К., Евхаристия..., op. cit., s. 165.
}

dla uporządkowania tekstów modlitwy anafory, powinna się raczej stać chęć zachowania przejrzystości treściowej, tak fundamentalna dla twórców antiocheńskiej syntezy eucharystycznej. Spójność treści, która potwierdza naukę eklezjalną Kościoła prawosławnego wydaje się wystarczającym powodem dla przeprowadzenia krytycznej redakcji tekstów.

Kończąc naszą analizę modlitw anafory i jej epikletycznych elementów, należałoby również wskazać na dodatkowe zadania związane z redakcją tych tekstów, jak również praktyki ich liturgicznego wygłaszania w trakcie Liturgii.

Do takich, pożądanych i oczekiwanych zadań należy zaliczyć:

1. Zmniejszenie akcentu położonego na dialogi kapłana i diakona, które przerywają modlitwę anafory. Do XIII w. słowa modlitwy anafory nie były przerywane żadnymi wezwaniami diakońskimi. Co więcej, stare rękopisy nie wskazywały na udział diakona w czasie anafory. Dopiero w jednym z rękopisów XIII w. (Kodeks moskiewski nr 381), pojawiają się słowa: „Pobłogosław władyko Święte Dary" ${ }^{\text {57 }}$. Nawet późniejsze rękopisy nie posiadały adnotacji na ten temat. O zmianie możemy mówić dopiero pod koniec XIV w., kiedy pojawiają się komentarze liturgiczne w „Diataksis” patriarchy Filoteusza, czyli tzw. „rubryki” wyjaśniające działania duchownych w trakcie nabożeństwa, obecnie zapisywane jako czerwone komentarze w księgach liturgicznych. Słowa diakona: „Wspomnij mnie grzesznego, władyko święty" wraz z odpowiedzią kapłana, zapisane w LitCHR, są umieszczone w modlitwie epiklezy. Zgodnie z zasadą spójności modlitwy anafory dialog ten powinien zostać przeniesiony na zakończenie modlitwy wstawienniczej, a więc przed kończącym anaforę wychwaleniem Imienia: „I daj nam jednymi ustami i jednym sercem sławić i opiewać najczcigodniejsze, i najwspanialsze imię Twoje, Ojca i Syna, i Świętego Ducha, teraz i zawsze, i na wieki wieków" ${ }^{\text {58. }}$.

2. Powrót do praktyki "cichego" czytania modlitwy anafory. O praktyce cichego czytania modlitwy anafory (por. późniejsza adnotacja gr. $\mu v \sigma \tau \iota \kappa \tilde{\omega} \varsigma$, cs. тайно) świadczy edykt cesarza Justyniana $(+565)$. Cesarz sprzeciwiał się jej, a nawet wydał specjalne postanowienie - 137 Novella, rozdz. 6, w którym nakazywał wygłaszać modlitwy pełnym głosem (łac. non in se(reto $)^{59}$. W dekrecie Justynian powoływał się m.in. na słowa ap. Pawła: „Bo jeśli będziesz błogosławił w duchu, jakże na twoje błogosławienie odpowie 'Amen' ktoś niewtajemniczony, skoro nie rozumie tego, co ty mówisz? Ty wprawdzie pięknie dzięki czynisz, lecz drugi tym się nie buduje" (1 Kor 14, 16-17). Pomimo cesarskiego w VIII w. modlitwy przestają być czytane głośno, co potwierdzają słowa św. patriarchy Germana (+730): „cicho wypowiadamy przed Bogiem tajemni-

\footnotetext{
57 Ibid., s. 194.

58 Boska Liturgia świętego ojca naszego Jana Chryzostoma, op. cit., s. 88.

59 Алымов В., Лекици..., ор. cit., s. 63; Голубцов А.П., О причинах и времени замены гласного чтения литургийных молитв тайными, „Богословский вестник”, 1905, nr 9, s. 73.
} 
ce". W komentarzach ojców nie brakowało słów krytyki i wątpliwości. Sam św. patriarcha German wyrażał swoje zdziwienie i krytykę w stosunku do nowej praktyki: „Jaki jest cel, myśl i moc cicho odczytywanych modlitw?" Jednak z czasem przyjęta $\mathrm{z}$ pokorą nowa praktyka stała się powszechna ${ }^{60}$. Sam termin $\mu v \sigma \tau \iota \kappa \tilde{\omega} \varsigma$ sprawia wiele problemów. Słowo to jest współcześnie rozumiane wyłącznie jako odnoszące się do sposobu wygłoszenia modlitwy, tj. wypowiadania jej „cicho”, podczas gdy ma także inne znaczenia, ukryte dla przykładu w pieśni cherubinów „My, którzy cherubinów mistycznie ( $\mu v \sigma \tau \iota \kappa \tilde{\omega} \varsigma$, cs. тайно) przedstawiamy". Zdaniem o. Henryka Paprockiego, termin ten określał "manierę recytacji modlitwy" 61 . Ciche czytanie modlitw, oprócz zmian w sposobie śpiewu, oddaliło wiernych od sprawowanego sakramentu, czyniąc go przed nimi ukrytym. Najlepiej świadczą o tym komentarze liturgiczne, które już w pierwszym tysiącleciu wyjaśniając wiernym znaczenie Liturgii, przechodzą od Symbolu Wiary bezpośrednio do Sanctusa oraz Modlitwy Pańskiej, ignorując przy tym znaczenie cicho czytanych modlitw anafory. W ten sposób Liturgię wyjaśniał już św. Maksym Wyznawca (ok. 630) ${ }^{62}$. W XI w. w komentarzu Liturgii pochodzącym z Małej Azji a określanym jako „Proteoria” (ok. 1085-1095), wyjaśniając słowa modlitwy czytanej przed amboną w końcu Liturgii zapisano, iż wyjaśnia ona wiernym sens i znaczenie niesłyszanych przez nich modlitw kanonu eucharystycznego ${ }^{63}$. Pożądanym rozwiązaniem kwestii „cichych” modlitw, mógłby stać się powrót do praktyki $\lambda \dot{\varepsilon} \gamma \omega v \mu \nu \sigma \tau \iota \kappa \omega ́ c$, tj. półgłośnej recytacji tych najważniejszych modlitw.

3. Wyolbrzymienie roli śpiewu w trakcie modlitwy anafory. Już archimandryta Kiprian Kern podkreślał, iż śpiew nie powinien naruszać treści modlitwy ${ }^{64}$. Powinien natomiast korespondować z długością modlitw. $\mathrm{W}$ trakcie śpiewu „Tobie śpiewamy, Ciebie błogosławimy..." kapłan czyta modlitwę epikletyczną i rozpoczyna modlitwę wstawienniczą. W 980 roku w czasie LitCHR, w momencie wygłaszania wstawienniczej modlitwy anafory, zaczęto śpiewać pieśń ku czci Bogurodzicy: "Zaprawdę godne jest” (cs. Достойно ecmb) ${ }^{65}$. Hymn nie kończy modlitwy wstawienniczej, a tym samym anafory, lecz jest śpiewany w jej trakcie. Niedo przyjęcia staje się skracanie tekstu modlitw w celu uniknięcia ciszy. Bizantynizacja nabożeństw ograniczyła modlitwy ciszy, które jednak są całkowicie dopuszczalne i świadczą o żarliwej modlitwie. W prak-

\footnotetext{
Zob. Алымов В., Леки,ии..., ор. cit., s. 117.

1 Paprocki H., Misterium..., op. cit., s. 241.

Тафт Р.Ф., Статьи. ІІ. Литургика, Голованов, Омск 2011, s. 293.

63 Ibid., s. 294-295. Więcej informacji o zmianie sposobu czytania modlitw kapłańskich możemy odnaleźć w artykułach o. Tafta: „Czy głośne czytanie modlitw było tradycją wczesnochrześcijańskiego Kościoła?” („Were Liturgical Prayers Once Recited Aloud?”) oraz „Anafora Eucharystyczna była wygłaszana cicho czy głośno?” („Was the Eucharistic Anaphora Recited Secretly or Aloud?"). Ibid., s. 253-302, 303-310.

${ }_{64}$ Керн К., Евхаристия..., ор. cit., s. 161.

65 Алымов В., Лекиии..., ор. cit., s. 63.
}

tyce ascetycznej IV w. mnisi śpiewali psalmy, przy czym po każdym zapadała cisza i wspólnota pogrążała się w wewnętrznej duchowej modlitwie. Nawet przy niewłaściwym tempie śpiewu, modlitwa wstawiennicza lub inne elementy modlitwy anafory powinny być przez kapłana kontynuowane, $\mathrm{z}$ zachowaniem świadomości znaczenia tychże modlitw.

4. Przywrócenie znaczenia modlitwy wstawienniczej anafory. „Służebniki” LitCHR i LitBAZ wskazują na liczne prośby o wstawiennictwo, które ma miejsce w najważniejszym momencie - nad przemienionymi Darami Eucharystycznymi, w trakcie śpiewu „Zaprawdę godne jest” lub 9 pieśni kanonu święta. $\mathrm{W}$ tym momencie, zgodnie z praktyką liturgiczną, kapłan ma nie tylko przeczytać wstawiennicze modlitwy „Służebnika” lecz również wspominać imiona żywych oraz umarłych ${ }^{66}$. Brak tej praktyki doprowadził do przeakcentowania ektenii Liturgii katechumenów a przez to doprowadził do zmiany miejsca wspomnienia tych, którzy proszą o modlitwę. Obecnie dokonuje się ono w trakcie proskomidii, co odpowiada praktyce ofiarowania darów eucharystycznych z jednoczesną prośbą o modlitwę za ofiarodawców, oraz w trakcie ektenii, gdzie wspomnienie imion ma miejsce jeszcze przed przemianą darów. $\mathrm{W}$ tekście LitCHR i LitBAZ znajdują się jednak wyraźne momenty w modlitwie wstawienniczej anafor, w czasie których należałoby odczytywać dyptychy za żywych i umarłych. Fragment „Pamiętaj i o tych, których nie wspomnieliśmy z niewiedzy, zapomnienia lub wielości imion. Sam o nich pamiętaj, Boże, który znasz imię i wiek każdego, który znasz każdego z łona jego matki” ${ }^{67}$, znajdujący się w tekście AnBAZ, Wasilij Bołotow określił następująco: „Zakończenie «których nie wspomnieliśmy» to nie tylko wspaniały przykład literackiej twórczości, lecz wskazuje odbicie niezwykłej praktyczności Bazylego, w czysto ludzkim rozumieniu. Potrzebne było aby liczba tych, «proszących nas niegodnych o modlitwy» została ograniczona przyjętą normą i jednocześnie «ze względu na świąteczny [charakter nabożeństwa - MŁ] nie zasmucać tych, których prośby o wspomnienie imion nie zostały wygłoszone z powodu "wielości imion»"68. Dla duszpasterskiej opieki i liturgicznej świadomości wiernych, warto przywrócić praktykę czytania imion w momencie modlitwy wstawienniczej. Jej sens opiera się na tym, by po dokonanej przemianie prosić Boga w intencji tych, którzy dla sprawowania ofiary przyszli do świątyni, uczestniczą w nabożeństwie i proszą o modlitwę za żywych i umarłych. Rozsądnym i nieinwazyjnym działaniem może być

\footnotetext{
Sz Szczegółową analizę właściwego momentu wspominania imion w trakcie modlitwy AnBAZ przeprowadził prof. W. Bołotow. Болотов B. B., op. cit., s. $295-296$.

67 Boska Liturgia świętego ojca naszego Bazylego Wielkiego, op. cit., s. $98-99$.

68 Болотов В. В., op. cit., s. 296. Tłum. MŁ.
} 
katecheza wiernych co do znaczenia tego momentu liturgicznego.

Wszystkie wnioski sprowadzają się do oczekiwania na przeakcentowanie modlitwy anafory w duchu prawosławnej teologii, odrzuceniu kontekstu „formuły sakramentalnej” w jej zachodnim rozumieniu. W tym działaniu pierwszym krokiem powinno być wyłączenie $\mathrm{z}$ modlitw anaforalnych troparionów nabożeństwa trzeciej godziny oraz usunięcie z tekstu AnBAZ słów „Przemieniając Duchem Twoim Świętym”. Równolegle należy dążyć do odkrywania głębi teologii liturgicznej, stanowiącej żywe potwierdzenie prawosławnego rozumienia Boga, świata i człowieka. Opiera- jąc się na przyczynach tworzenia prawosławnych tradycji liturgicznych (jerozolimskiej, studyjskiej, katedralnej i innych), teologia prawosławnego nabożeństwa powinna się stać narzędziem ewangelizacyjnym i katechizacyjnym.

W sytuacji wykorzystywania $\mathrm{w}$ polskiej praktyce liturgicznej ksiąg drukowanych w różnych ośrodkach, m.in. w Polsce, Rosji, na Ukrainie, praktycznym krokiem do realizacji przedstawionych wyżej celów powinna się stać krytyczna redakcja cerkiewnosłowiańskich i polskich tekstów Liturgii oraz ich opublikowanie po akceptacji przez Sobór Biskupów Polskiego Autokefalicznego Kościoła Prawosławnego jako obowiązujących „Służebników”.

\section{Bibliografia}

Pismo Święte Starego i Nowego Testamentu, Biblia Tysiąclecia, Wydawnictwo Pallottinum 2003, IV.

Boska Liturgia świętego ojca naszego Bazylego Wielkiego, Warszawska Metropolia Prawosławna, Warszawa 2005.

Boska Liturgia świętego ojca naszego Jana Chryzostoma, Warszawska Metropolia Prawosławna, Warszawa 2001.

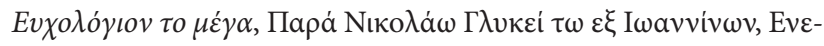

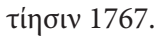

Соловецзкий Служебник, РНБ. Солов. № 1017.

Wieczernia, Jutrznia, Prokimenony, Alleluja, Rozesłania, Kalendarz Liturgiczny, Warszawska Metropolia Prawosławna, Warszawa 2006.

Алымов В., Лекции по Исторической Литургике, Holy Trinity Orthodox School b.d., maszynopis.

Арранц М., Евхаристия Востока и Запада, Москва 1999.

Арранц М., і Рубан Ю., История византийского типикона “Око иерковное". Часть I. Предвизантийская эпоха. Исторические свидетельства о молитве древних християн (до V в.), Журнал “Нева," Санкт-Петербург 2003.

Baron A., i Pietras H. (red.), Konstytucje świętych apostołów [spisane] przez Klemensa, [w:] Konstytucje apostolskie oraz Kanony Pamfilosa $z$ apostolskiego synodu w Antiochii, Prawo kanoniczne świętych Apostołów, Kary świętych Apostołów dla upadłych, Euchologion Serapiona, Wydawnictwo WAM, Księża Jezuici, Kraków 2007, vol. II.

Болотов В. В., Заметки по поводу текста литургии св. Васития Великого. Письмо архиепископу финляндскому Антонию, „Христианское чтение”, 1914, nr 3, s. 281-298.

Деснов Николай, Еще несколько слов об известных расхождениях между русскими и греками в литургиях святителей Василия Великого и Иоанна Златоуста, w: Богословские труды, 31 1992, s. 86-96.

Голубцов А. П., Литургия в первые века христианства (I), „Богословский вестник”, 1913, nr 7/8, s. 621-643.

Голубцов А. П., Литургия в первые века христианства (III), „Богословский вестник”, 1913, nr 12, s. 779-802.
Голубцов А. П., О причинах и времени замены гласного чтения титургийных молитв тайными, „Богословский вестник”, 1905, nr 9, s. 69-75.

Goar J., Euchologion Sive Rituale Graecorum, Graz 1960, II.

Hipolit Rzymski, Tradycja Apostolska, [w:] Antologia literatury patrystycznej. T. I, red. M. Michalski, PAX, Warszawa 1975, s. 300-316.

Jan Chryzostom, św., Dialog o kapłaństwie, Wydawnictwo M, Kraków 2009.

Kabasilas M., Komentarz Boskiej Liturgii św. Jana Chryzostoma, tłum. M. Ławreszuk, Warszawska Metropolia Prawosławna, Warszawa 2009.

Карабинов И. А., Лекизи по литургике. Читанныя студентам (ХIX) и (ХХ) курсов С. Петербургской Духовной Академии в 1911-1912 уи. году, Литография Богданова, Санкт-Петербург 1912.

Керн К., Евхаристия, Москва 1999.

Матеос Х., Развитие византийской титургии, [w:] Развитие византийской титургии, tłum. N. Vasilevich, Quo Vadis, Киев 2009.

Орлов М. И., Литургия святаго Василия Великого, Синодальная типография, Санкт-Петербург 1909.

Paprocki H., Misterium Eucharystii. Interpretacja genetyczna liturgii bizantyjskiej, Wydawnictwo WAM, Kraków 2010.

Parenti S. i Velkovska E., red., L'Eucologio Barberini gr. 336, C. L.V. -Edizioni Liturgiche, Roma 1995.

Скабалланович М., Толковый Типикон. Объяснительное избяснение Типика с историческим введением, Издание Сретенского монастыря, Москва 2004.

Тафт Р. Ф., Статьи. ІІ. Литургика, Голованов, Омск 2011.

Захарович Ф., Чин титургии св. Иоанна Златоустого по изложению старопечатных, новоисправленного и древлеписменных Служебников: Опыт сличения старопечатных и исправленных иерковнобогослужебных книг с древлеписьменными, Москва 1899. 